\title{
Henri-Paul Francfort, Frantz Grenet, Guy Lecuyot, Bertille Lyonnet, Laurianne Martinez-Sève, Claude Rapin (éds.). Il y a 50 ans... la découverte d'Aï Khanoum. 1964-1978, fouilles de la Délégation archéologique française en Afghanistan (DAFA)
}

\section{Vito Messina}

\section{(2) OpenEdition}

\section{Electronic version}

URL: http://journals.openedition.org/abstractairanica/42650

DOI: 10.4000/abstractairanica.42650

ISBN: 1961-960X

ISSN: 1961-960X

Publisher:

CNRS (UMR 7528 Mondes iraniens et indiens), Éditions de l'IFRI

\section{Electronic reference}

Vito Messina, « Henri-Paul Francfort, Frantz Grenet, Guy Lecuyot, Bertille Lyonnet, Laurianne MartinezSève, Claude Rapin (éds.). Il y a 50 ans... la découverte d'Aï Khanoum. 1964-1978, fouilles de la Délégation archéologique française en Afghanistan (DAFA) », Abstracta Iranica [Online], Volume 37-38-39 | 2018, document 22, Online since 10 March 2018, connection on 26 September 2020. URL : http:// journals.openedition.org/abstractairanica/42650; DOI : https://doi.org/10.4000/abstractairanica. 42650

This text was automatically generated on 26 September 2020 .

Tous droits réservés 


\title{
Henri-Paul Francfort, Frantz Grenet, Guy Lecuyot, Bertille Lyonnet, Laurianne Martinez-Sève, Claude Rapin (éds.). Il y a 50 ans... la découverte d'Aï Khanoum. 1964-1978, fouilles de la Délégation archéologique française en Afghanistan (DAFA)
}

\author{
Vito Messina
}

\section{REFERENCES}

Henri-Paul Francfort, Frantz Grenet, Guy Lecuyot, Bertille Lyonnet, Laurianne Martinez-Sève, Claude Rapin (éds.). Il y a 50 ans... la découverte d'Aï Khanoum. 1964-1978, fouilles de la Délégation archéologique française en Afghanistan (DAFA), Paris, De Boccard, 2014, 118 p. with figs.

This book is published fifty years after the first discoveries made by the Délégation archéologique française en Afghanistan (DAFA) at Ai Khanoum, in northeast Afghanistan, one of the most important sites for the study of what we call 'Hellenized Orient'. Already known since the late $19^{\text {th }}$ century, the site was truly discovered in 1961, at the chance of a royal hunt in the Darqat Island Reserve. During this hunt, Mohammad Zahir Shah noticed a Greek-inspired stone capital and requested Marc Le Berre's expertise. The latter alerted D. Schlumberger, at that time director of the DAFA, who planned the first expedition at the site. The excavations conducted there between 1964 and 1978 gradually revealed the existence of a large Greek city, a discovery that definitively 
modified our perception of Hellenism. If the status of the city is not easy to be defined, there can be little doubts that Ai Khanoum is a characteristic centre of the Hellenistic world. Founded at the beginning of the $3^{\text {rd }}$ century $\mathrm{BC}$ in the ancient region of Bactria, it was settled by a population of Greek origin, whose traditions were perpetuated by their descendants for nearly one hundred and fifty years, before the site was abandoned in around $145 \mathrm{BC}$. As the description of the main monuments shows, Ai Khanoum was divided between two cultures, having been inhabited by a mixed population of Orientalized Greco-Macedonians and Hellenized local Iranians. The settlers of Greek origin followed their traditions and culture deeply, as evidenced by the presence of a gymnasium and theatre, even if the visually Greek architectural decoration was plastered on buildings whose plans suggest eastern influences. Different authors contributed to this book, displaying the history of research and the many discoveries made by the French school, as the table of contents clearly reveals: 'Entre France et Afghanistan'; 'Le site'; 'Les découvertes archéologiques'; 'Les fortifications' (G.Lecuyot); 'La nécropole hors les murs' (G.Lecuyot), 'L'ensemble palatial' (G.Lecuyot and C. Rapin); 'Les sanctuaires' (L.Martinez Sève and G.Lecuyot);'Le gymnase' (G.Lecuyot); 'Le théâtre' (F. Grenet); 'L'arsenal' (F. Grenet); 'L'habitat' (G.Lecuyot); 'La vie économique et la culture matérielle' (H.-P. Francfort and B.Lyonnet); 'Les bases économiques d'Aï Khanoum' (B.Lyonnet); 'La culture matérielle' (H.-P. Francfort); 'La céramique' (B.Lyonnet); 'Aï Khanoum, ville de la Bactriane hellénistique' (L. Martinez-Sève); 'Aï Khanoum dans le temps long'; 'L'arrivée des Grecs'; 'Le développement urbain d'Aï Khanoum et ses étapes'; 'Aï Khanoum sous Eucratide Ier';'La nouvelle Eucratidéia'; 'La fin d'Aï Khanoum'; 'Aï Khanoum hier et aujourd'hui' (G.Lecuyot); 'Images d'Aï Khanoum en 3D'.

\section{AUTHORS}

\section{VITO MESSINA}

Università di Torino 